\section{Refining Postharvest Handling Procedures Increased Cut Rose Vase Life}

\author{
Erin P. Moody, John M. Dole ${ }^{1}$, and Jared Barnes
}

AdDitional INDEX wORDs. Rosa bybrida, 1-methylcyclopropene, ethylene, silver thiosulfate, senescence

SUMMARY. Various postharvest procedures were conducted on several rose (Rosa bybrida) cultivars to determine the effects on vase life, water uptake, change in fresh weight, stage of opening, and vase life termination criteria. Vase life was influenced by cultivar and vase solution. Commercial preservative solutions resulted in a longer vase life, smaller decrease in fresh weight than the controls, and smaller increase in water uptake. Vase life of nine cultivars in distilled water ranged from a low of 7.1 days for Queen 2000 to a high of 15.3 days for Forever Young. Flower termination criteria were also cultivar specific with Black Baccara, Classy, and Charlotte most prone to bent neck and blackening of petal tips. Exogenous ethylene at 0.4 or $4.0 \mu \mathrm{L} \cdot \mathrm{L}^{-1}$ did not affect vase life but lowered water uptake. Application of the antiethylene agent silver thiosulfate (STS) at $0.2 \mathrm{~mm}$ concentration significantly improved vase life in five out of the nine cultivars (Anna, Charlotte, First Red, Freedom, and Konfetti) tested, but 1 -methylcyclopropene (1-MCP) at $740 \mathrm{~nL} \cdot \mathrm{L}^{-1}$ did not improve vase life over the control. Both vase life and water uptake were reduced when more than one stem was placed in a vase; placing 10 stems in a vase shortened vase life by 1.4 days and impeded water uptake by up to $10.6 \mathrm{~mL} / \mathrm{stem}$ per day. Increasing the amount of time stems remained dry before placing in a vase reduced vase life, but recutting immediately before placing in a vase minimized the decline. Increasing the amount of stem cut off the base up to $10 \mathrm{~cm}$ increased vase life.

$\mathrm{T}$ he cut flower industry faces many challenges due to the difficulty in producing flowers with a long postharvest vase life. To ensure a longer vase life, growers must carefully regulate postharvest conditions and postharvest handling methods.

Water uptake is one of the most important factors in improving the length of vase life of cut flowers (Halevy and Mayak, 1979). As the leaves on the flowers transpire, water is drawn up through the xylem. If this process is impeded by a vascular blockage or accelerated by increased stomatal opening, transpiration will exceed uptake and water deficiency will occur. Thus, solutes are frequently added to vase solutions such as 8hydroxyquinoline citrate (8-HQC), which can increase water uptake (van

Department of Horticultural Science, North Carolina State University, Box 7609, Raleigh, NC 27695

We gratefully acknowledge funding from Dole Fresh Flowers and support from the floriculture research technicians Ingram McCall and Diane Mays and graduate students Emma Locke and Erin Regan.

Mention of a trademark, proprietary product, or vendor does not constitute a guarantee or warranty of the product by North Carolina State University and does not imply its approval to the exclusion of other products or vendors that also may be suitable.

${ }^{1}$ Corresponding author. E-mail: john_dole@ncsu.edu.
Doorn, 1997). To ensure quality product, rose growers, wholesalers, and retailers should understand the effects of additives or preservatives in vase solutions on rose vase life. While adding sucrose to a vase solution will increase vase life, it also allows increased bacterial proliferation that then requires the addition of antimicrobial compounds to vase solutions to minimize occlusions in the stem from bacteria. For example, the addition of 8-HQC to vase solutions reduced bacteria levels found in the bottom $5-\mathrm{cm}$ segment of 'Sonia' rose stems from $840,000 \mathrm{cfu} / \mathrm{g}$ fresh weight to less than $120 \mathrm{cfu} / \mathrm{g}$ fresh weight (van Doorn, 1990). A low pH solution produced by the addition of sodium hypochlorite and a $\mathrm{pH} 3.0$ buffer also reduced bacteria levels and increased water conductance in several rose cultivars (Marousky, 1971; van Doorn, 1990). Sucrose decreased water absorption in 'Better Times' roses; however, Marousky (1969, 1971) determined that sucrose extended vase life. In 'First Red', vase life increased over the control when held in a vase solution containing up to $1.5 \%$ sucrose and vase life declined with higher concentrations of sucrose up to $3 \%$ (Singh et al., 2003). Bhattacharjee (1994) found in a study on 10 rose cultivars that the use of a preservative solution containing $300 \mathrm{mg} \cdot \mathrm{L}^{-1} 8$-HQC and $1 \%$ sucrose increased vase life vs. using distilled water. The extent of the increase varied by cultivar from 1.0 to $2.7 \mathrm{~d}$. Ketsa et al. (1993) found that using a holding solution containing $5 \%$ sucrose and $20 \mathrm{mg} \cdot \mathrm{L}^{-1}$ silver nitrate significantly improved the vase life of 'Eiffel Tower', 'Swartmore', and 'Yankee' roses, but did not improve vase life of 'King's Ransom' or 'Confidence'.

Ethylene, a naturally occurring plant hormone, is another postharvest factor that can negatively impact flower quality. Thus, some producers use antiethylene agents to minimize its effects (Dole and Wilkins, 2005). The effect of ethylene and antiethylene agents on cut rose flowers is varied and appears to be cultivar dependent. On a test with 38 cut rose cultivars, $1 \mu \mathrm{L} \cdot \mathrm{L}^{-1}$ exogenous ethylene shortened vase life of 27 cultivars, impeded the rate of flower opening in six cultivars, and had no effect on five cultivars (Macnish et al., 2010). RueySong et al. (2001) noted that a 0.1 - to $2-\mu \mathrm{L} \cdot \mathrm{L}^{-1}$ exogenous application of ethylene significantly decreased vase life in 'Golden Medal' cut roses but had less of an effect on 'Grand Gala' vase life. Ethylene at $0.5 \mu \mathrm{L} \cdot \mathrm{L}^{-1}$ inhibited (three cultivars), accelerated

\begin{tabular}{llll}
\hline $\begin{array}{l}\text { Units } \\
\begin{array}{l}\text { To convert U.S. to SI, } \\
\text { multiply by }\end{array}\end{array}$ & U.S. unit & Sl unit & $\begin{array}{l}\text { To convert SI to U.S., } \\
\text { multiply by }\end{array}$ \\
\hline 29.5735 & $\mathrm{fl} \mathrm{oz}$ & $\mathrm{mL}$ & 0.0338 \\
3.7854 & gal & $\mathrm{L}$ & 0.2642 \\
2.54 & inch $(\mathrm{es})$ & $\mathrm{cm}$ & 0.3937 \\
1 & $\mathrm{mmho} / \mathrm{cm}$ & $\mathrm{dS} \cdot \mathrm{m}^{-1}$ & 1 \\
28.3495 & $\mathrm{oz}$ & $\mathrm{g}$ & 0.0353 \\
0.001 & $\mathrm{ppm}$ & $\mathrm{g} \cdot \mathrm{L}^{-1}$ & 1000 \\
1 & $\mathrm{ppm}$ & $\mathrm{mg} \cdot \mathrm{L}^{-1}$ & 1 \\
0.001 & $\mathrm{ppm}$ & $\mathrm{mL} \cdot \mathrm{L}^{-1}$ & 1000 \\
1 & $\mathrm{ppm}$ & $\mu \mathrm{L} \cdot \mathrm{L}^{-1}$ & 1 \\
$\left({ }^{\circ} \mathrm{F}-32\right) \div 1.8$ & ${ }^{\circ} \mathrm{F}$ & ${ }^{\circ} \mathrm{C}$ & $\left({ }^{\circ} \mathrm{C} \times 1.8\right)+32$
\end{tabular}


( 14 cultivars), or had no effect (five cultivars) on flowering opening (Reid et al., 1989). For the effects of antiethylene agents, Reid et al. (1989) noted that STS could overcome the effects of exogenous ethylene. Singh et al. (2004) found that STS improved the vase life in three of seven rose cultivars tested, and Macnish et al. (2010) showed that STS could prevent an ethylene-induced drop in vase life in three ethylene sensitive cultivars.

Contrasting reports exist on the efficacy of 1-MCP. Philosoph-Hadas et al. (2005) found that treating stems with $0.4 \mu \mathrm{L} \cdot \mathrm{L}^{-1} \mathrm{l}$-MCP for $4 \mathrm{~h}$ increased vase life for rose cultivars Pink Tango, Jazz, Frisco, and Golden Gate compared with ethylene-exposed control stems, and Macnish et al. (2010) found that various types of 1-MCP treatment prevented the negative effects of exogenous ethylene. However, Chamani et al. (2005) found that treating stems with $1 \mu \mathrm{L} \cdot \mathrm{L}^{-1} \mathrm{l}$ MCP for $2 \mathrm{~h}$ did not improve vase life in 'First Red'. The effects of ethylene and antiethylene agents on water uptake are also not known.

The application of postharvest research to the industry has always been a concern of researchers, and there appears to be limited information about how the number of stems per vase and recutting time impacts postharvest quality. Restrictions on availability of plant materials and time to collect data usually limit the number of stems per replication in research. Commercial cut flower growers, wholesalers, and retailers typically group rose stems in bunches of 10 or more and also place dozens of bunches in each bucket as the flowers are harvested, processed, and marketed. For postharvest evaluation, commercial tests are usually conducted using whole bunches with 10 or more stems, while university research often uses replications of one, three, or five stems per vase. Also, after receipt of roses, stems are usually recut to increase vase life (Dole and Wilkins, 2005). However, questions still remain about how changing drying time after recutting the stem, drying time before recutting the stem, and the amount of the stem recut impacts postharvest floral quality.

Therefore, the objectives of this research were to quantify the effects of 1) various vase solutions, 2) application of exogenous ethylene and antiethylene compounds before and after shipment, 3) stem number in a vase, and 4) postharvest dry storage on the postharvest performance of several cut rose cultivars.

\section{Materials and methods}

Postharvest environment. Unless otherwise indicated, Colombiangrown rose stems were harvested and received within $4 \mathrm{~d}$, unpacked, sorted based on stem caliper, processed by recutting to $45 \mathrm{~cm}$, removing the lower third of the foliage, and placed in vases (1-qt Mason jars; Ball, Muncie, IN) filled with $400 \mathrm{~mL}$ of the indicated solutions with three stems per vase. Additional solution was added as needed to maintain at least $100 \mathrm{~mL}$. Treatments and vase life determinations were conducted at $20 \pm$ $\mathrm{l}^{\circ} \mathrm{C}$ under 20 to $40 \mu \mathrm{mol} \cdot \mathrm{m}^{-2} \cdot \mathrm{s}^{-1}$ light for $12 \mathrm{~h} \cdot \mathrm{d}^{-1}$ at $40 \%$ to $60 \%$ relative humidity $(\mathrm{RH})$.

Design and DATA COLleCtion. Unless indicated in the sections below, the experiment was arranged in a completely randomized design with five replications of three stems (subsamples) each per vase. Vase life was recorded for every experiment, with vase life termination determined by one or more of the following criteria: the presence of bent neck (Fig. 1A), wilted petals (Fig. IB), or the occurrence of black tips (Fig. 1C) on at least three petals. Data were analyzed using analysis of variance (version 9.3; SAS Institute, Cary, NC), and means were separated using Tukey's Studentized range test at $P \leq 0.05$. Trend analysis was also conducted where appropriate.

EXPT. 1: Cultivars and vase SOLUTION EVALUATIONS. Rose stems of the following nine cultivars were used: Black Baccara, Black Magic, Charlotte, Classy, First Red, Forever Young, Freedom, Queen 2000, and Rouge Baiser. Within 4 h of receipt, stems of each cultivar were sorted into five uniform groups, processed, and placed into the following solutions: 1) $0.1 \mathrm{~g} \cdot \mathrm{L}^{-1}$ calcium hypochlorite and $0.74 \mathrm{~g} \cdot \mathrm{L}^{-1}$ aluminum sulfate $(\mathrm{Ca}+\mathrm{Al})$ in tap water $[\mathrm{pH} 3.7$, electrical conductivity (EC) $\left.0.73 \mathrm{dS} \cdot \mathrm{m}^{-1}\right]$; 2) $10 \mathrm{~g} \cdot \mathrm{L}^{-1}$ of a propriety mixture of sugar, acidifier, and a biocide [CHR (Chrysal Professional \#3; Chrysal, Miami, FL)] in tap water $\left(\mathrm{pH} 2.8\right.$, EC $\left.0.49 \mathrm{dS} \cdot \mathrm{m}^{-1}\right) ; 3$ )
$10 \mathrm{~g} \cdot \mathrm{L}^{-1}$ a propriety mixture of sugar, acidifier and a biocide [FLO (Floralife $^{\circledR}$ Crystal Clear packets; Floralife, Walterboro, SC)] in tap water $(\mathrm{pH}$ 3.1, EC $\left.0.50 \mathrm{dS} \cdot \mathrm{m}^{-1}\right) ; 4$ ) deionized water (pH 3.8, EC $\left.0.00 \mathrm{dS} \cdot \mathrm{m}^{-1}\right)$; or 5) tap water $(\mathrm{pH}$ 6.6, EC 0.25 $\left.\mathrm{dS} \cdot \mathrm{m}^{-1}\right)$. Data collected included initial and termination fresh weight and water uptake measured at termination. Reasons for termination and stage of flower opening were also recorded. Stage of openness was recorded as 0 for tight (petals upright, some outer petals may be slightly reflexed); 1 for medium (all whorls beginning to reflex); 2 for open (outer whorls completely reflexed, all whorls reflexing to a high degree); and 3 for fully open (stamens visible).

EXPT. 2: ANTIETHYLENE AgENT TREATMENT IN NORTH CAROLINA. Stems of six rose cultivars (Charlotte, Classy, First Red, Forever Young, Freedom, and Rouge Baiser) were sorted upon receipt into nine uniform groups, processed, and placed into vases. The vases were placed in sealed metal barrels for $4 \mathrm{~h}$ containing $\mathrm{l}$ ) $0.74 \mu \mathrm{L} \cdot \mathrm{L}^{-1} \quad \mathrm{l}-\mathrm{MCP}$ (Ethylbloc ${ }^{\mathrm{TM}}$, Floralife);2) $0.2 \mathrm{~mm} \mathrm{STS}\left[1.0 \mathrm{~mL} \cdot \mathrm{L}^{-1}\right.$ AVB (Chrysal) in tap water]; or 3) ambient air. After this pretreatment, vases were resealed in barrels and exposed to $4.0,0.4$, or $0 \mu \mathrm{L} \cdot \mathrm{L}^{-1}$ ethylene for $24 \mathrm{~h}$. Reasons for termination and stage of flower opening were also recorded, as described in the previous experiment.

Expt. 3: Antiethylene agent TREATMENT IN COLOMbia. Three 25stem bunches of four rose cultivars (Anna, Charlotte, Freedom, and Konfetti) were pretreated on a Colombian farm with either STS or water for $4 \mathrm{~h}$ and then packed, stored, and shipped to Raleigh, NC. Bunches were received $9 \mathrm{~d}$ after pretreatment, at which point they were transferred to tap water and stems of each cultivar were sorted into four uniform groups, processed, and placed into the following solutions: 1 ) $10 \mathrm{~g} \cdot \mathrm{L}^{-1} \mathrm{CHR}$ in tap water $(\mathrm{pH} 2.8$, EC $\left.\left.0.49 \mathrm{dS} \cdot \mathrm{m}^{-1}\right) ; 2\right) 10 \mathrm{~g} \cdot \mathrm{L}^{-1} \mathrm{FLO}$ in tap water $\left(\mathrm{pH} 3.1, \mathrm{EC} 0.50 \mathrm{dS} \cdot \mathrm{m}^{-1}\right)$; or $3)$ deionized water $(\mathrm{pH} 3.8$, EC 0.00 $\left.\mathrm{d} S \cdot \mathrm{m}^{-1}\right)$. Half of the stems in deionized water were exposed to $1.0 \mu \mathrm{L} \cdot \mathrm{L}^{-1}$ ethylene in a sealed barrel for $24 \mathrm{~h}$. Data collected included initial fresh weight and fresh weight and water uptake measured $4 \mathrm{~d}$ after placement of stems in vases. 

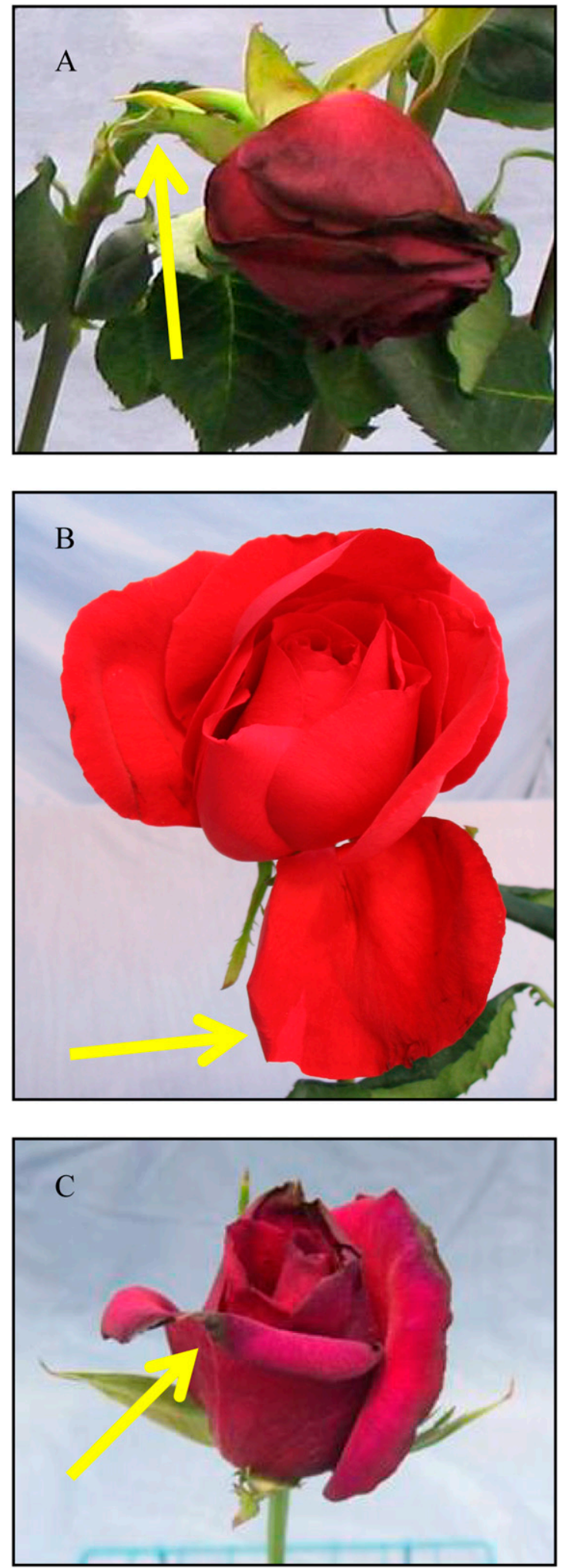

Fig. 1. Rose cut stem termination criteria included (A) bent neck exhibited on 'Black Baccara', (B) wilted petals exhibited on 'Rouge Baiser', or (C) black tips exhibited on 'Charlotte'.

EXPT. 4: STEM NUMBER PER VASE. Stems of three rose cultivars (Charlotte, Classy, and Freedom) were sorted upon receipt into four uniform

groups and processed. Stems were placed in vases filled with $500 \mathrm{~mL}$ of tap water ( $\mathrm{pH} 6.6$, EC $\left.0.25 \mathrm{dS} \cdot \mathrm{m}^{-1}\right)$. Each vase contained $1,3,5$, or 10 stems of the same cultivar, and each treatment included 10 replicate vases. Data collected included water uptake at termination.

Expt. 5: Postharvest DRY HANDLING AND RECUTTING. Stems of three rose cultivars (Charlotte, Classy, and Freedom) were sorted upon receipt into eight uniform groups, recut to $48 \mathrm{~cm}$ (first cut), and placed in buckets at $20^{\circ} \mathrm{C}$ containing $5 \mathrm{~L}$ of tap water to rehydrate overnight. Stems were then evaluated for drying time after recutting, before recutting, and recutting amount. To evaluate drying time after recutting, stems were recut to $45 \mathrm{~cm}$ (second cut) and placed dry at $20 \pm 1{ }^{\circ} \mathrm{C}$ and $40 \%$ to $60 \% \mathrm{RH}$ for $0,10,20,60$, or $120 \mathrm{~min}$ or 4,24 , or $48 \mathrm{~h}$ before being placed in vases filled with $500 \mathrm{~mL}$ of tap water. To evaluate drying time before recutting, stems were placed dry at $20 \pm$ $1{ }^{\circ} \mathrm{C}$ and $40 \%$ to $60 \% \mathrm{RH}$ for 0,10 , 20,60 , or $120 \mathrm{~min}$ or 4,24 , or $48 \mathrm{~h}$ before being recut (second cut with a removal of $2.5 \mathrm{~cm}$ off the stem base) and placed in vases filled with $500 \mathrm{~mL}$ of tap water. To evaluate recutting amount, stems were placed dry at $20 \pm 1{ }^{\circ} \mathrm{C}$ and $40 \%$ to $60 \% \mathrm{RH}$ for $24 \mathrm{~h}$ before being recut (second cut) with a removal of $0,1,2,3,4,5$, 10 , or $15 \mathrm{~cm}$ off the stem base and then placed in vases filled with 500 $\mathrm{mL}$ of tap water.

\section{Results and discussion}

PosthaRvest QUALITy FOR CULTIVARS AND VASE SOLUTIONS. In Expt. 1, the greatest vase life was observed in 'Forever Young' with the treatments of $\mathrm{Ca}+\mathrm{Al}$, the two commercial preservatives, and DI water (15.2-16.2 d), and the lowest vase life was in the DI and tap water treatments for 'Queen 2000' [7.2 d (Table 1)]. Stage of opening (on a 0-3 scale) was greatest in 'Queen 2000' for $\mathrm{Ca}+\mathrm{Al}$ and the commercial preservatives (2.73.0), and lowest with 'First Red' in $\mathrm{Ca}+\mathrm{Al}$, DI water, and tap water (Table 1). In Expts. 2 and 3, vase life range was $3.3 \mathrm{~d}[6.2 \mathrm{~d}$ for 'Rouge Baiser' (data not presented) to $9.5 \mathrm{~d}$ for 'Freedom' (Table 2)] and $7.3 \mathrm{~d}$ (8.1 d for 'Anna' to $15.4 \mathrm{~d}$ for 'Konfetti' (Table 3)], respectively. For Expts. 1-3, these ranges were consistent with previous cultivar studies. Nell and Leonard (2004) studied 16 rose cultivars and reported up to a $10 \mathrm{~d}$ difference in vase life and a range of 1.3 to 3.9 (on 
Table 1. Effect of various vase solutions on vase life, stage of opening, water uptake, and change in fresh weight of nine rose cultivars. Solutions included calcium hypochlorite and aluminum sulfate $(\mathrm{Ca}+\mathrm{Al})$ in tap water; two propriety mixtures of sugar, acidifier and biocide (CHR and FLO) in tap water; deionized (DI) water; or tap water.

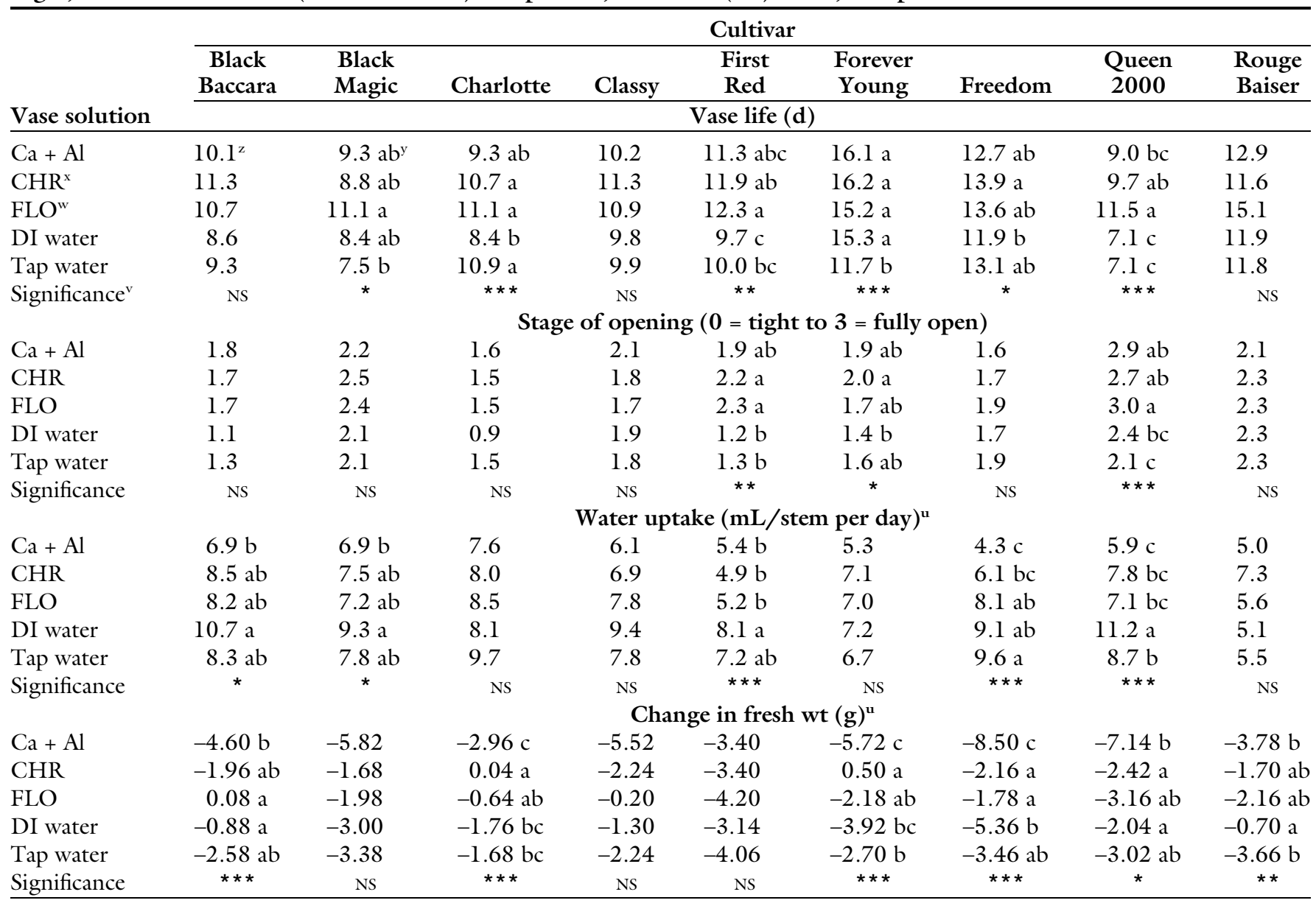

${ }^{\mathrm{z}}$ Means are an average of five replications of three stems each. For all variables, cultivar was significant at $P \leq 0.0001$, vase solution at $P \leq 0.0001$, and cultivar $\times$ vase solution at $P \leq 0.004$.

y Means followed by the same letter within each variable are not significantly different at $P \leq 0.05$ using Tukey's Studentized range test.

xChrysal Professional \#3 (Chrysal, Miami, FL).

"Floralife ${ }^{\circledast}$ Crystal Clear packets (Floralife, Walterboro, SC).

${ }^{* *},{ }^{* *}$, or $* * *$ indicates statistically significant differences between sample means based on $\mathrm{F}$ test at $P<0.05, P<0.01$, or $P<0.001$, respectively. NS (Ns) indicates $\mathrm{F}$ test for differences between sample means had $P>0.05$.

${ }^{\mathrm{u}} \mathrm{l} \mathrm{mL}=0.0338 \mathrm{fl} \mathrm{oz}, \mathrm{lg}=0.0353 \mathrm{oz}$.

Table 2. Effect of stems treated in North Carolina with 1-methylcyclopropene (1-MCP), silver thiosulfate (STS), or air (control) on vase life of three rose cultivars.

\begin{tabular}{lccr}
\hline & \multicolumn{3}{c}{ Cultivar } \\
\cline { 2 - 4 } Pretreatment & Charlotte & First Red & Freedom \\
\cline { 2 - 4 } l-MCP & $8.6 \mathrm{ab}^{\mathrm{z}}$ & $6.0 \mathrm{~b}$ & \\
STS & $9.2 \mathrm{a}$ & $7.6 \mathrm{a}$ & $9.2 \mathrm{~b}$ \\
Air & $7.4 \mathrm{~b}$ & $5.2 \mathrm{~b}$ & $10.6 \mathrm{a}$ \\
Significance $^{\mathrm{y}}$ & $*$ & $* * *$ & $8.6 \mathrm{~b}$ \\
& $* * *$ \\
\hline
\end{tabular}

${ }^{2}$ Means followed by the same letter are not significantly different at $P \leq 0.05$ using Tukey's Studentized range test. Means are an average of 13-15 replicates of three stems each. No significant interactions between antiethylene agent and ethylene concentration occurred.

${ }^{y *}$ or $* * *$ indicates statistically significant differences between sample means based on $\mathrm{F}$ test at $P<0.05$ or $P<$ 0.001 , respectively.

a 1-4 scale) difference in flower opening, Macnish et al. (2010) evaluated 38 cultivars and reported up to a $14.3 \mathrm{~d}$ difference in vase life and a 3.2 (on a 1-5 scale) difference in flower opening, and Durkin and Kuc (1966) studied four cultivars and reported up to a $6 \mathrm{~d}$ difference in vase life.
Similar to our results from Expt. 1, Macnish et al. (2010) determined that 'Forever Young' was one of the longest lasting cultivars, and 'Black Magic' one of the shortest lived cultivars, and Nell and Leonard (2004) found that 'First Red' had a longer vase life than 'Black Magic' (Table 1). It should be noted that the cut roses in these experiments were commercially produced and, consequently, a portion of the variation in vase life could have been due to differences in harvest time during the day, environmental conditions, and so forth (Fanourakis et al., 2013).

Of the five vase solutions tested in Expt. 1, the commercial preservatives, CHR and FLO, produced a similar vase life for all nine cultivars tested 
and resulted in the longest vase life across all cultivars of $11.7 \mathrm{~d}$ and $12.4 \mathrm{~d}$, respectively [Table 1 (averages not presented)]. These two preservatives contain carbohydrates, which have been reported to increase vase life (Marousky, 1969, 1971; Mor et al., 1989). The $\mathrm{Ca}+\mathrm{Al}$ treatment produced a similar vase life (average of $11.2 \mathrm{~d}$ ) to the commercial preservative treatments in a majority of the cultivars tested, which could be due to the antimicrobial properties attributed by $\mathrm{Ca}+\mathrm{Al}$ (van Doorn et al., 1989).

Average water uptake was greatest in both DI water and tap water treatments across all cultivars in Expt. $\mathrm{l}$; average values were 8.7 and 7.9 $\mathrm{mL} /$ stem per day, respectively (Table 1). Though water uptake has been demonstrated to be positively correlated with vase life of croton [Codiaeum variegatum (Hettiarachchi and Balas, 2005)], uptake can be inhibited by the addition of sucrose to a vase solution (Marousky, 1971). This impediment in uptake is thought to be due to the high $\psi_{\mathrm{s}}$ of concentrated sucrose solutions and the ability of sucrose to induce closure of stomata (Marousky, 1969, 1971).

In the first experiment, average water uptake of cultivars across all solutions ranged from $8.5 \mathrm{~mL} / \mathrm{stem}$ per day for Black Baccara to $5.7 \mathrm{~mL} /$ stem per day for Rouge Baiser [Table 1 (averages not shown)]. Variability

Table 3. Vase life of stems of four rose cultivars that were pretreated with silver thiosulfate (STS) or water in Colombia before being shipped to North Carolina.

\begin{tabular}{lc}
\hline & $\begin{array}{c}\text { Pretreatment } \\
\text { vase life }(\mathbf{d})\end{array}$ \\
\hline STS & $13.5 \mathrm{a}^{\mathrm{z}}$ \\
Water & $12.3 \mathrm{~b}$ \\
Significance' & Cultivar vase life $(\mathbf{d})$ \\
'Anna' & $8.1 \mathrm{c}$ \\
'Charlotte' & $13.5 \mathrm{~b}$ \\
'Freedom' & $14.6 \mathrm{a}$ \\
'Konfetti' & $15.4 \mathrm{a}$ \\
Significance & $* * *$
\end{tabular}

${ }^{2}$ Means within cultivar or pretreatment followed by the same letter are not significantly different at $P \leq$ 0.05 using Tukey's Studentized range test. Means are an average of 40 replicates of three stems each for cultivar and 80 replicates of three stems each for pretreatment. No interactions $(P=0.05)$ between cultivar and pretreatment occurred.

$y * * *$ indicates statistically significant differences between sample means based on $\mathrm{F}$ test at $P<0.001$. be due to differences in xylem anatomy, which has been reported to greatly influence hydraulic conductivity (Nijsse et al., 2001; Twumasi et al., 2005). van Doorn and Reid (1995) did not find significant differences in xylem anatomy among rose cultivars Frisco, Sonia, Madelon, and Cara Mia; however, Twumasi et al. (2005) found that water availability during preharvest environment can affect xylem vessel diameter. Since all cultivars were not produced in the same greenhouses, it is possible that some cultivars experienced more water stress than others during production, which might have affected the xylem properties within the stems and water uptake.

Treatments with commercial preservatives also inhibited fresh weight loss; averages for the two commercial preservatives, CHR and FLO, were -1.7 and $-1.8 \mathrm{~g}$, respectively (Table 1 , averages not shown). Marousky (1969) found similar results with cut 'Better Times' roses and concluded that because floral preservatives helped maintain fresh weight while still causing less water uptake, measuring remaining solution in a vase to determine transpiration did not yield accurate results. In addition, Ichimura et al. (1999) and Marousky (1969, 1971) reported that sucrose maintains fresh weight due to its ability to increase carbohydrate levels in petals and induce stomatal closure. Average change in fresh weight was variable among cultivars, with treatments causing no significant differences in change in fresh weight in three of the nine cultivars tested.

Termination CRITERIA FOR CUltivar AND VASE SOlution. Termination criteria proved to be cultivar dependent in Expt. 1. 'Black Baccara' among cultivars of water uptake may

and 'Charlotte' were more susceptible to postharvest problems than others; however, in general, cultivars were ended because the stems developed multiple problems during the vase life evaluation period. Physiological processes occurring in cut rose stems are complex and often interrelated such that determining the specific causes of termination symptoms is difficult (Zieslin, 1989).

A common cause of rose termination was bent neck. In Expt. 1, 'Black Baccara', 'Charlotte', and 'Classy' developed bent neck in $32.2 \%, 29.2 \%$, and $26.7 \%$ of the cases, respectively, while bent neck occurred in 'Black Magic' and 'First Red' 1.1\% and $2.2 \%$ of the time, respectively $[P \leq$ 0.0001 (data not presented)]. An interaction between cultivar and vase solution occurred for the presence of bent neck $(P=0.0025)$ where bent neck occurred most frequently in $\mathrm{Ca}+$ $\mathrm{Al}(20 \%)$ and DI water (47\%) for 'Freedom' and most frequently in DI water $(53 \%)$ and tap water $(20 \%)$ for 'Classy' (data not presented). No differences in the occurrence of bent neck were seen among vase solutions in the other seven cultivars tested. 'Classy' and 'Rouge Baiser' had the highest rates of bent neck in Expt. 2 (Table 4). Bent neck has been attributed to the presence of embolisms in the stem that restrict water flow (Burdett, 1970). These embolisms are thought to be mostly bacterial in nature (Burdett, 1970; Reid et al., 1996) because the addition of compounds with bactericidal effects greatly limited the occurrence of bent neck (Ohkawa et al., 1999). However, water flow restriction has also been attributed to blockage caused by particulates such as proteins and gums that clog the xylem (Burdett, 1970; Reid

Table 4. Effect of treatment with antiethylene agents after receipt in North Carolina on occurrence of termination criteria in six rose cultivars.

\begin{tabular}{lccc}
\hline Cultivar & Bent neck (\%) & Black tips (\%) & Wilted petals (\%) \\
\hline Charlotte & $12 \mathrm{bc}^{\mathrm{z}}$ & $33 \mathrm{~b}$ & $93 \mathrm{ab}$ \\
Classy & $25 \mathrm{a}$ & $3 \mathrm{c}$ & $82 \mathrm{~b}$ \\
First Red & $1 \mathrm{c}$ & $7 \mathrm{c}$ & $95 \mathrm{ab}$ \\
Forever Young & $1 \mathrm{c}$ & $4 \mathrm{c}$ & $54 \mathrm{c}$ \\
Freedom & $5 \mathrm{bc}$ & $77 \mathrm{a}$ & $57 \mathrm{c}$ \\
Rouge Baiser & $17 \mathrm{ab}$ & $1 \mathrm{c}$ & $99 \mathrm{a}$ \\
Significance $^{\mathrm{y}}$ & $* * *$ & $* * *$ & $* * *$ \\
\hline
\end{tabular}

${ }^{z}$ Means followed by the same letter are not significantly different at $P \leq 0.05$ using Tukey's Studentized range test. Means are an average of 43 to 45 stems. There was no interaction $(P=0.05)$ between the antiethylene agents and cultivar.

$\mathrm{y} * * *$ indicates statistically significant differences between sample means based on $\mathrm{F}$ test at $P<0.001$. 
et al., 1996). These physical blockages have been reported to occur about $10 \mathrm{~cm}$ above the level of the vase solution (Lineberger and Steponkus, 1976).

Blackening of petal tips was another commonly observed problem in several cultivars. In Expt. 1, 'Black Baccara', 'Charlotte', and 'Freedom' developed black tips (57\% to $71 \%$ ) more often $(P \leq 0.0001)$ than the other cultivars (data not presented). 'Freedom' and 'Charlotte' also developed more black tips than the other cultivars in Expt. 2 (Table 4). Similar tip blackening has also been reported to appear in other red rose cultivars such as Mercedes and Jaguar, where black tip development was attributed to both an exposure to ultraviolet radiation and low temperatures during growth (Jaffrin, 2002; Mor and Zieslin, 1990; Raviv, 1988). Barendse (1981) also observed petal tip blackening in gerbera (Gerbera jamesonii) due to the use of a vase life preservative, which is consistent with the results of the current study where black tip was most prevalent in the commercial preservatives.

Stems were also ended due to wilted petals, which was the most common reason for termination in all cultivars. In Expt. 1, wilted petals occurred most frequently in $\mathrm{Ca}+\mathrm{Al}$, FLO, and DI water (73\% to $93 \%$ ) in 'Forever Young' and ranged from $27 \%$ in $\mathrm{Ca}+\mathrm{Al}$ to $80 \%$ in FLO for 'Charlotte' (data not presented). No differences in the occurrence of wilted petals were seen among vase solutions in the other seven cultivars tested. 'Charlotte', 'First Red', and 'Rouge Baisier' had the highest rates of wilted petals in Expt. 2 (Table 4). In both experiments, wilted petals occurred in over $50 \%$ of stems in every cultivar across treatments. This petal wilting was most likely due to high transpiration losses that exceed water uptake at some point during vase life and trigger wilting when insufficient water is available to the petals (Carpenter and Rasmussen, 1973).

Antiethylene Agents And ETHYLENE. STS significantly increased vase life in three of the six cultivars treated in North Carolina in Expt. 2. 'First Red' and 'Freedom' had at least a $2 \mathrm{~d}$ increase in vase life when treated with STS as compared with the air storage control (Table 2). 'Classy', 'Forever Young', and 'Rouge Baiser' were unaffected by pretreatment with either antiethylene agent (data not presented). Pretreating stems with STS in Colombia in Expt. 3 before storage and shipping significantly increased vase life by $1.2 \mathrm{~d}$ across all cultivars (Table 3). Similarly, Macnish et al. (2010) reported that STS prevented shortening of vase life from exposure to exogenous ethylene in all three cultivars studied, and Reid et al. (1989) reported that STS prevented the effects of exogenous ethylene in 22 of 27 cultivars. Singh et al. (2004) reported an increase in vase life due to STS in rose cultivars Grand Gala, Sangria, and Kiss but not in four other cultivars tested. When applied in Colombia (Expt. 3), STS did not affect water uptake or change in rose fresh weight (data not presented).

Chamani et al. (2005) found that 'First Red' vase life was extended with a $0.5 \mathrm{~mm}$ STS application but not l-MCP treatment, which is consistent with the results for 'First Red' and the other five cultivars tested in this study where l-MCP did not significantly improve vase life (Table 2). 1-MCP applied either as a fumigation or via sachets prevented a decrease in vase life from exogenous ethylene in one of three cultivars studied by Macnish et al. (2010). Xue et al.

Table 5. Vase life (cultivar $P \leq \mathbf{0 . 0 0 0 1}$, treatment $P=\mathbf{0 . 0 7 9 3}$, cultivar $\times$ treatment $P=0.0045$ ) or water uptake measured $4 \mathrm{~d}$ after placement in vase (cultivar $P \leq 0.0001$, treatment $P \leq 0.0001$, cultivar $\times$ treatment $P=0.0215$ ) of stems of four rose cultivars pretreated with silver thiosulfate (STS) or water in Colombia before being shipped to North Carolina and then treated with one of two propriety mixtures of sugar, acidifier and a biocide (CHR and FLO) in tap water; deionized (DI) water, or $1.0 \mu \mathrm{L} \cdot \mathrm{L}^{-1}(\mathrm{ppm})$ ethylene plus DI water.

\begin{tabular}{lcccc}
\hline & \multicolumn{4}{c}{ Cultivar } \\
\cline { 2 - 5 } Treatment & Anna & \multicolumn{4}{c}{ Charlotte } & Freedom & Konfetti \\
\cline { 2 - 5 } & \multicolumn{5}{c}{ Vase life $(\mathbf{d})$} \\
CHR $^{\mathrm{z}}$ & 7.9 & $14.9 \mathrm{a}^{\mathrm{y}}$ & $15.2 \mathrm{a}$ & 15.3 \\
FLO $^{\mathrm{x}}$ & 7.6 & $14.4 \mathrm{a}$ & $15.5 \mathrm{a}$ & 14.9 \\
DI & 8.2 & $13.0 \mathrm{ab}$ & $14.6 \mathrm{ab}$ & 15.5 \\
Ethylene + DI & 8.5 & $11.8 \mathrm{~b}$ & $13.3 \mathrm{~b}$ & 15.9 \\
Significance & $\mathrm{N}$ & $* * *$ & $* *$ & $\mathrm{NS}$ \\
& & Water uptake & $(\mathrm{mL} / \mathrm{stem})^{\mathrm{v}}$ & \\
CHR & $33.2 \mathrm{a}$ & $33.7 \mathrm{a}$ & $32.3 \mathrm{a}$ & $23.3 \mathrm{a}$ \\
FLO & $30.7 \mathrm{a}$ & $30.3 \mathrm{a}$ & $29.5 \mathrm{a}$ & $20.7 \mathrm{a}$ \\
DI & $31.5 \mathrm{a}$ & $27.8 \mathrm{a}$ & $23.0 \mathrm{~b}$ & $19.3 \mathrm{ab}$ \\
Ethylene + DI & $23.8 \mathrm{~b}$ & $19.0 \mathrm{~b}$ & $18.7 \mathrm{~b}$ & $15.3 \mathrm{~b}$ \\
Significance & $* * *$ & $* * *$ & $* * *$ & $* * *$ \\
\hline
\end{tabular}

${ }^{\mathrm{z} C h r y s a l ~ P r o f e s s i o n a l ~ \# 3 ~(C h r y s a l, ~ M i a m i, ~ F L) . ~}$

y Means followed by the same letter are not significantly different at $P \leq 0.05$ using Tukey's Studentized range test. Means are an average of 10 replicates of three stems each. No interactions $(P \leq 0.05)$ between pretreatment and post shipping treatments occurred. Data were averaged over STS treatment.

${ }^{\mathrm{x}}$ Floralife ${ }^{\circledR}$ Crystal Clear packets (Floralife, Walterboro, SC).

$w * *$ or $* * *$ indicates statistically significant differences between sample means based on $\mathrm{F}$ test at $P<0.01$ or $P<$ 0.001 , respectively. Nonsignificant (NS) indicates $F$ test for differences between sample means had $P>0.05$. ${ }^{\mathrm{v}} 1 \mathrm{~mL}=0.0338 \mathrm{fl} \mathrm{oz}$. 
$P \leq 0.05$. Lukaszewska et al. (1990) reported that a $7-\mathrm{d}$ exposure to ethylene was needed for an increase in petal drop to be observed.

For all cultivars, water uptake was the lowest for flowers treated with 1.0 $\mu \mathrm{L} \cdot \mathrm{L}^{-1}$ ethylene but varied from a low of $15.3 \mathrm{~mL} / \mathrm{stem}$ in 'Konfetti' to a high of $23.8 \mathrm{~mL} / \mathrm{stem}$ in 'Anna' (Table 5). Mayak and Halevy (1972) found that applying ethylene to rose stems increased abscisic acid (ABA)-like production. In addition, Kumar et al. (2008) noted that water uptake decreased in cut roses as ABA and ethylene levels increased during senescence.

The increases in vase life due to STS revealed that STS may be playing another role in the stem other than acting solely as an antiethylene agent. For example, STS improved vase life regardless of exogenous ethylene application for cut 'First Red' and 'Sonia' roses (Chamani et al., 2005; Lukaszewska et al., 1990). Even though the primary use of STS is ethyleneaction inhibition, STS has also been shown to exhibit antimicrobial characteristics (Al-Humaid, 2004), which could be why vase life was improved in stems treated with STS even when exogenous ethylene had no effect.

The question remains as to the benefit for commercial use of STS and 1-MCP. Macnish et al. (2010) and Reid et al. (1989) noted that $86 \%$ and $81 \%$ of cultivars tested were sensitive to exogenous ethylene, respectively, and Macnish et al. (2010) found that on average exogenous ethylene decreased vase life by an average of $2.2 \mathrm{~d}$. In contrast, for species such as carnation (Dianthus caryophyllus) and delphinium (Delphinium $\times$ cultorum) where antiethylene agents are commonly used, exogenous ethylene shortened vase life more dramatically;

Table 6. Effect of stem number per vase on vase life of rose.

\begin{tabular}{lc}
\hline Stems (no./vase) & Vase life $(\mathrm{d})$ \\
\hline 1 & $10.9 \mathrm{a}^{\mathrm{z}}$ \\
3 & $10.5 \mathrm{a}$ \\
5 & $10.2 \mathrm{ab}$ \\
10 & $9.5 \mathrm{~b}$ \\
Significance $^{\mathrm{y}}$ & $* *$ \\
\hline
\end{tabular}

${ }^{\mathrm{z}}$ Means followed by the same letter are not significantly different at $P \leq 0.05$ using Tukey's Studentized range test. Means are an average of 30 vases where each vase contained one, three, five, or 10 stems. Cultivar did not influence vase life, and no interactions $(P \leq 0.05)$ between stem number and cultivars occurred.

$\mathrm{y} * *$ indicates statistically significant differences between sample means based on $\mathrm{F}$ test at $P<0.01$ for example, $0.53 \mu \mathrm{L} \cdot \mathrm{L}^{-1}$ exogenous ethylene shortened carnation vase life from 16 to $3 \mathrm{~d}$ (Staby et al., 1993). In addition, while STS is generally effective at preventing damage from exogenous ethylene, especially when applied before shipping, l-MCP is less effective than STS (Blankenship and Dole, 2003). Therefore, the potential vase life decrease from exogenous ethylene is probably not sufficient to warrant the standard treatment of STS or 1-MCP on all cultivars. However, the use of STS may be cost-effective in the case of high value cultivars that are sensitive to ethylene, premium grades where the treatment cost can be recovered, or when cut stems are stored or shipped for long durations.

It is worth noting vase solution (FLO, CHR, or DI) did not affect vase life in this experiment and only affected water uptake for 'Freedom' (Table 5). DI water resulted in lower water uptake than the preservative treatments in this case, which is inconsistent with the findings in Expt. 1 for the effects of preservative solutions on water uptake (Table 1). However, for experiment 3, uptake was recorded $4 \mathrm{~d}$ after the start of vase life instead of at termination, which could account for the difference observed. Since water uptake is highest immediately after harvest (Doi et al., 1999; Mayak et al., 1974) and at the commencement of rehydration, differences in water uptake among the treatments may have occurred later than $4 \mathrm{~d}$ after the start of vase life.

STEMS Per vase. In Expt. 4, placing 10 stems in a vase resulted in the shortest vase life of $9.5 \mathrm{~d}$ across all cultivars, and placing one to five stems in a vase resulted in the longest vase life (Table 6). Water uptake across all cultivars was greatest with fewer stems placed in a vase, from 6.1 $\mathrm{mL} /$ stem per day with 10 stems per vase to $14.1 \mathrm{~mL} / \mathrm{stem}$ per day with one stem per vase [Table 7 (averages

Table 7. Effect of stem number per vase on water uptake of three rose cultivars (cultivar $P=0.0013$, stems $/$ vase $P \leq 0.0001$, cultivar $\times$ stems $/$ vase $P=0.0067$ ).

\begin{tabular}{lccc}
\hline & \multicolumn{4}{c}{ Cultivar } \\
\cline { 2 - 4 } Stems (no./vase) & \multicolumn{2}{c}{ Charlotte } & \multicolumn{2}{c}{ Classy } & Freedom \\
\cline { 2 - 4 } & $16.9 \mathrm{a}^{\mathrm{y}}$ & $12.2 \mathrm{a}$ & $13.3 \mathrm{a}$ \\
3 & $8.5 \mathrm{~b}$ & $9.0 \mathrm{~b}$ & $7.7 \mathrm{~b}$ \\
5 & $8.5 \mathrm{~b}$ & $7.2 \mathrm{bc}$ & $6.8 \mathrm{~b}$ \\
10 & $6.3 \mathrm{~b}$ & $6.2 \mathrm{c}$ & $5.8 \mathrm{~b}$ \\
Significance $^{\mathrm{x}}$ & $* * *$ & $* * *$ & $* * *$ \\
\hline
\end{tabular}

${ }^{z} 1 \mathrm{~mL}=0.0338 \mathrm{fl} \mathrm{oz}$

${ }^{\mathrm{y}}$ Means followed by the same letter are not significantly different at $P \leq 0.05$ using Tukey's Studentized range test. Means are an average of 10 vases where each vase contains one, two, five, or 10 stems.

**** indicates statistically significant differences between sample means based on $\mathrm{F}$ test at $P<0.001$.

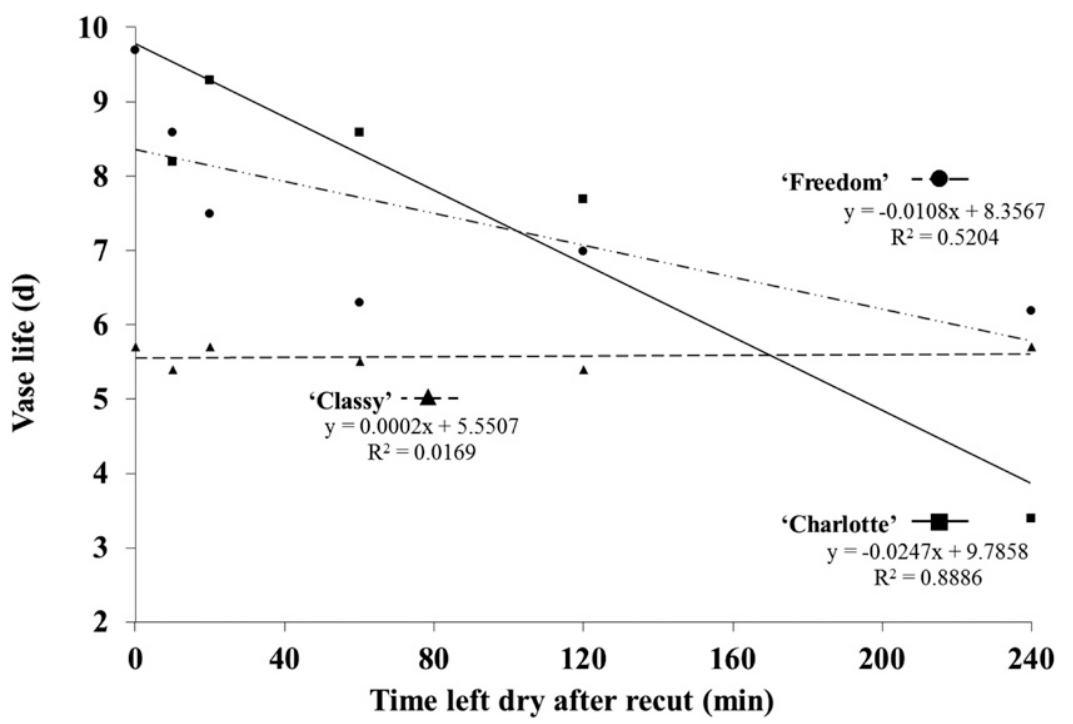

Fig. 2. Effect of drying time after recutting on vase life of 'Charlotte', 'Classy', and 'Freedom' rose stems. 
not shown)]. The shortening of vase life and decrease in water uptake could be due to greater amounts of bacteria and cellular contents in the vase water from the increased number of stems per vase, which clog the stem xylem and increase water flow resistance (Burdett, 1970). In addition, the presence of multiple stems in a vase may have reduced air movement around the leaves in the middle of each bunch, decreasing transpiration and water uptake.

DRYING TIME AND RECUTTING. In Expt. 5, allowing cut rose stems to remain dry for any amount of time before placement in solution shortened vase life; however, the extent of that shortening was dependent on cultivar and when the stems were recut. The vase lives of 'Charlotte' and 'Freedom' both declined when stems were left to dry longer after being recut (Fig. 2), but vase life could be improved if the stems were recut after being left dry (Fig. 3). 'Classy' was more durable, maintaining an vase life of $5.6 \mathrm{~d}$ when left dry for up to $240 \mathrm{~min}$ after being recut. Recutting stems of 'Classy' and 'Charlotte' immediately before placement in vases did not significantly shorten vase life for up to $24 \mathrm{~h}$ (1440 min). 'Charlotte' did not rehydrate at all, and 'Freedom' and 'Classy' had vase lives of only 1.7 and $1.5 \mathrm{~d}$, respectively, when allowed to dry for $24 \mathrm{~h}$ after being recut (data not presented). None of the three cultivars tested rehydrated when remaining dry for $48 \mathrm{~h}$. Rose stems are regularly shipped and stored dry for $48 \mathrm{~h}$ or more; however, in those cases temperatures are typically lower than the $20{ }^{\circ} \mathrm{C}$ used in this study. Nell and Leonard (2005) found that storing roses at $10{ }^{\circ} \mathrm{C}$ shortened vase life by up to $8 \mathrm{~d}$ in 13 of the 14 cultivars tested. Recutting any amount off the stem significantly improved vase life (Fig. 4). Recutting $10 \mathrm{~cm}$ off the stems resulted in the maximum vase life of $8.4 \mathrm{~d}$, and not recutting the stems resulted in the minimum vase life of $5.3 \mathrm{~d}$.

\section{Conclusions}

Overall, our findings demonstrate how to increase postharvest quality, and this research will help growers, wholesalers, and retailers provide a superior product to consumers. Although vase life varied by cultivar, commercial preservatives should be used in vase solutions to maximize the vase life of cut roses. Cultivar selection is important as there was over 1 week difference in vase life from the shortest to the longest lasting cultivar. Preservative solutions produced an average lower water uptake per day than control solutions but also minimized fresh weight loss. Flower termination criteria was also cultivar specific with Black Baccara, Classy, and Charlotte most prone to bent neck and blackening of petal tips. Exogenous ethylene had no effect on vase life; however, use of the antiethylene agent STS significantly improved vase life in several cultivars possibly due to minimizing the effects of endogenous ethylene action or due to the chemical's antimicrobial properties. Placing more than one stem per vase reduced water uptake, but vase life was only significantly reduced by placing 10 stems in a vase. Increasing the amount of time stems remained dry before placing in water shortened vase life. Recutting stem ends before placing in water was effective in minimizing losses in vase life due to long exposure of stems to air, where recutting $10 \mathrm{~cm}$ off stem ends resulted in roses

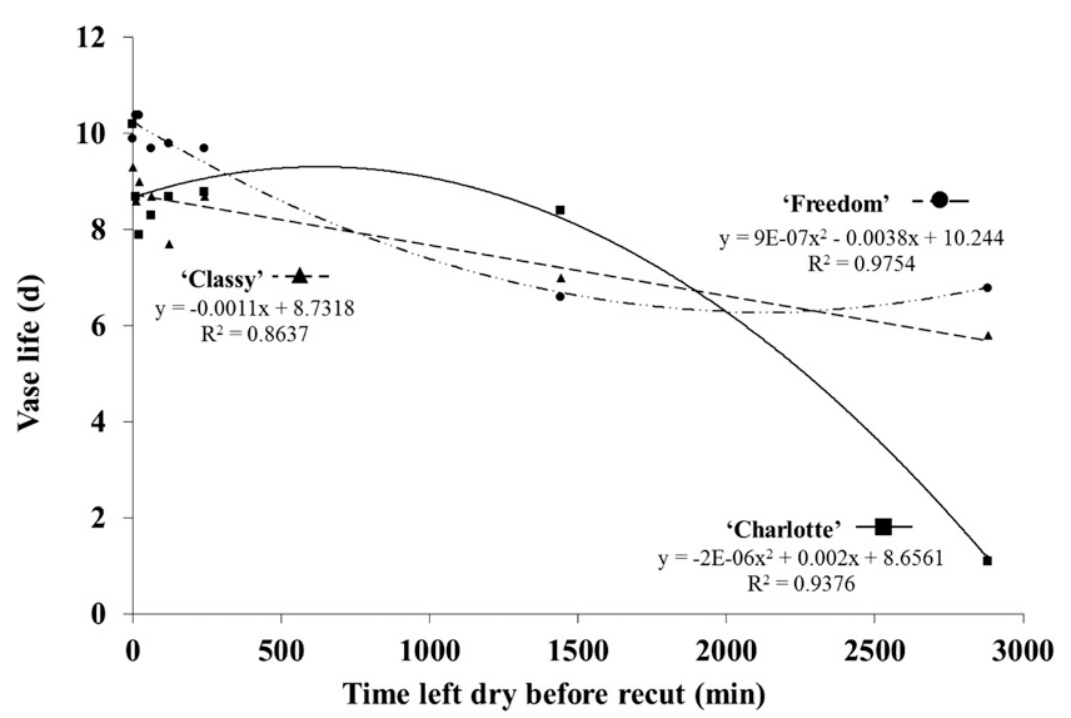

Fig. 3. Effect of drying time before recutting on vase life of 'Charlotte', 'Classy', and 'Freedom' rose stems.

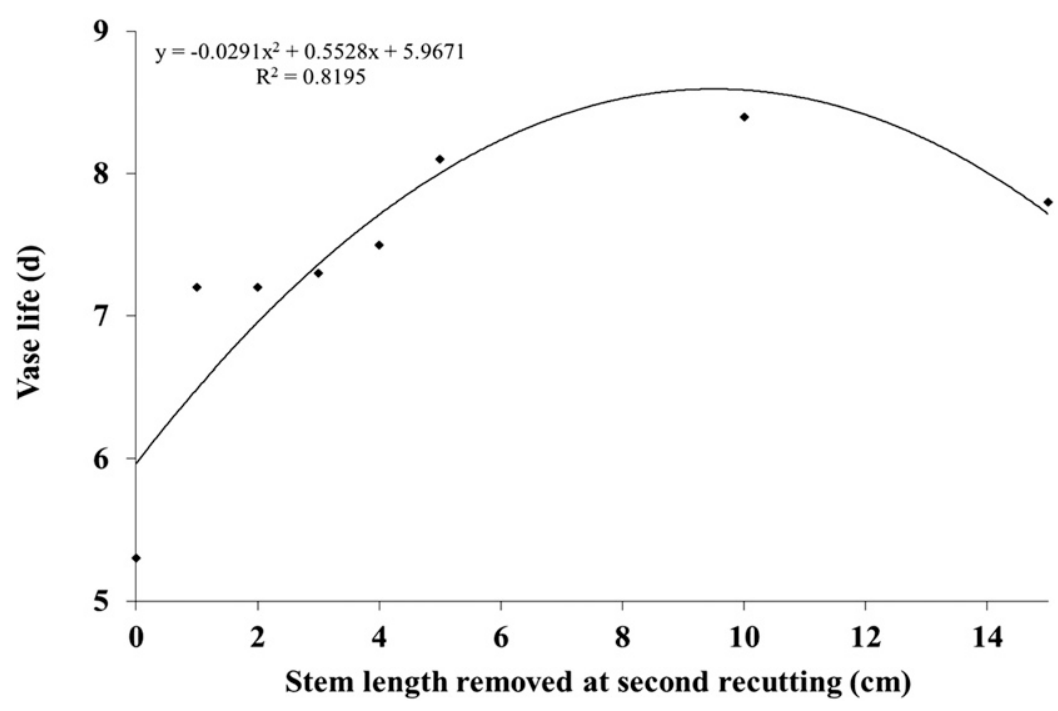

Fig. 4. Effect of recutting amount on vase life of 'Charlotte', 'Classy', and 'Freedom' rose stems. Cultivar was not significant and no interactions $(P=0.05)$ between cultivar and recutting amount occurred; $1 \mathrm{~cm}=0.3937$ inch. 
with the longest vase life. Leaving stems dry for $48 \mathrm{~h}$ is not recommended because this practice resulted in either the inability of the stems to rehydrate when recut before experiencing water stress or a decreased vase life when recut after experiencing water stress.

\section{Literature cited}

Al-Humaid, A.I. 2004. Silver thiosulfate prolongs vase life and improves quality of cut gladiolus and rose flowers. J. Food Agr. Environ. 2:296-300.

Barendse, L. 1981. The causes of stem damage to gerberas. Vakblad voor de Bloemisterij 36:29.

Bhattacharjee, S.K. 1994. Postharvest life of cut roses as affected by varietal differences. South Indian Hort. 42:331334.

Blankenship, S. and J.M. Dole. 2003. 1-Methylcyclopropene: A review. Postharvest Biol. Technol. 28:1-25.

Burdett, A.N. 1970. The cause of bent neck in cut roses. J. Amer. Soc. Hort. Sci. 95:427-431.

Carpenter, W.J. and H.P. Rasmussen. 1973. Water uptake rates by cut roses (Rosa bybrida) in light and dark. J. Amer. Soc. Hort. Sci. 98:309-313.

Chamani, E., A. Khalighi, D.C. Joyce, D.E. Irving, Z.A. Zamani, Y. Mostofi, and M. Kafi. 2005. Ethylene and antiethylene treatment effects on cut 'First Red' rose. J. Appl. Hort. 7:3-7.

Doi, M., M. Miyangawa-Namao, K. Inamoto, and H. Imanishi. 1999. Rhythmic changes in water uptake, transpiration and water potential of cut roses as affected by photoperiods. J. Jpn. Soc. Hort. Sci. 68:861-867.

Dole, J.M. and H.F. Wilkins. 2005. Floriculture principles and species. 2nd ed. Pearson-Prentice Hall, Upper Saddle River, NJ.

Durkin, D. and R. Kuc. 1966. Vascular blockage and senescence of the cut rose flower. Proc. Amer. Soc. Hort. Sci. 89:683-688.

Fanourakis, D., R. Pieruschka, A. Savvides, A.J. Macnish, V. Sarlikioti, and E.J. Woltering. 2013. Sources of vase life variation in cut roses: A review. Postharvest Biol. Technol. 78:1-15.

Halevy, A.H. and S. Mayak. 1979. Senescence and postharvest physiology of cut flowers. Part 1. Hort. Rev. 1:204236.
Hettiarachchi, M.P. and J. Balas. 2005. Croton ('Codiaeum variegatum (L.) Blume Excellent'): An evaluation of foliage performance after shipment and of vase water treatments to maintain vase life. Acta Hort. 669:343-349.

Ichimura, K., K. Kojima, and R. Goto. 1999. Effects of temperature, 8 hydroxyquinoline sulphate and sucrose on the vase life of cut rose flowers. Postharvest Biol. Technol. 15:33-40.

Jaffrin, A. 2002. Rose blackening under various types of greenhouse covers. Plasticulture 3:10-21.

Ketsa, S., F. Thampitakorn, and C. Piluek. 1993. Effects of silver nitrate and silver thiosulfate on vase-life of cut roses. Kasetsart J. Natural Sci. 27:91-97.

Kumar, N., G.C. Srivastava, and K. Dixit. 2008. Hormonal regulation of flower senescence in rose (Rosa bybrida L.). Plant Growth Regulat. 55:65-71.

Lineberger, R.D. and P.L. Steponkus. 1976. Identification and localization of vascular occlusions in cut roses. J. Amer. Soc. Hort. Sci. 101:246-250.

Lukaszewska, A.J., J. Tonecki, E.J. Woltering, and N. Gorin. 1990. Effect of ethylene and silver thiosulfate on vase life of 'Sonia' roses. Gartenbauwissenschaft 55:118-121.

Macnish, A.J., R.T. Leonard, A.M. Borda, and T.A. Nell. 2010. Genotypic variation in the postharvest performance and ethylene sensitivity of cut rose flowers. HortScience 45:790796.

Marousky, F.J. 1969. Vascular blockage, water absorption, stomatal opening, and respiration of cut 'Better Times' roses treated with 8-hydroxyquinoline citrate and sucrose. J. Amer. Soc. Hort. Sci. 94:223-226.

Marousky, F.J. 1971. Inhibition of vascular blockage and increased moisture retention in cut roses induced by $\mathrm{pH}, 8$-hydroxyquinoline citrate, and sucrose. J. Amer. Soc. Hort. Sci. 96:38-41.

Mayak, S. and A.H. Halevy. 1972. Interrelationships of ethylene and $a b$ scisic acid in the control of rose petal senescence. Plant Physiol. 50:34l346.

Mayak, S., A.H. Halevy, S. Sagie, A. BarYosef, and B. Bravdo. 1974. The water balance of cut rose flowers. Physiol. Plant. $32: 15-22$.

Mor, Y., F. Johnson, and J.D. Faragher. 1989. Preserving the quality of coldstored rose flowers with ethylene antagonists. HortScience 24:640-641.
Mor, Y. and N. Zieslin. 1990. U.V.-induced blackening of rose petals. Environ. Exp. Bot. 30:455-462.

Nell, T.A. and R.T. Leonard. 2004. Identifying long-lasting cut rose varieties. Amer. Floral Endowment Spec. Res. Rpt. No. 416.

Nell, T.A. and R.T. Leonard. 2005. The effect of storage temperatures on Colombian grown cut rose varieties. Acta Hort. 669:337-342.

Nijsse, J., G.W. van der Heijden, W. van Ieperen, C.J. Keijzer, and U. van Meeteren. 2001. Xylem hydraulic conductivity related to conduit dimensions along chrysanthemum stems. J. Expt. Bot. 52:319327.

Ohkawa, K., Y. Kasahara, and J. Suh. 1999. Mobility and effects on vase life of silver-containing compounds in cut rose flowers. HortScience 34:112-113.

Philosoph-Hadas, S., O. Golan, I. Rosenberger, S. Salim, B. Kochanek, and S. Meir. 2005. Efficiency of 1MCP in neutralizing ethylene effects in cut flowers and potted plants following simultaneous or sequential application. Acta Hort. 669:321-328.

Raviv, M. 1988. Ultraviolet radiation effect on blackening of rose petals. Appl. Agr. Res. 3:302-304.

Reid, M.S., L.L. Dodge, Y. Mor, and R.Y. Evans. 1989. Effects of ethylene on rose opening. Acta Hort. 261:215-220.

Reid, M.S., M. Mokhtari, J.H. Lieth, W.G. van Doorn, and R.Y. Evans. 1996. Modelling the postharvest life of cut roses. Acta Hort. 424:137-144.

RueySong, L., S. MeiLian, and L. SueFen. 2001. Effect of exogenous ethylene and ethylene inhibitor on flower physiology of cut rose 'Grand Gala' and 'Golden Medal' J. Chinese Soc. Hort. Sci. 47:281-290.

Singh, K., P.J. Singh, and J.S. Arora. 2003. Effect of sucrose on vase life of cut roses. J. Ornamental Hort. 6:145146.

Singh, K., P.J. Singh, and R. Kumar. 2004. Effect of some chemicals on keeping quality of cut roses. Adv. Hort. Sci. 18:161-167.

Staby, G.L., R.M. Basel, M.S. Reid, and L.L. Dodge. 1993. Efficacies of commercial anti- ethylene products for fresh cut flowers. HortTechnology 3:199-202.

Twumasi, P., W. van Ieperen, E.J. Woltering, A.M.C. Emons, J.H.N. Schel, J.F.H. Snel, U. van Meeteren, and D. van Marwijk. 2005. Effects of water stress during growth on xylem anatomy, xylem 
functioning, and vase life in three Zinnia elegans cultivars. Acta Hort. 669:303-311.

van Doorn, W.G. 1990. Hydroxyquinoline citrate and low $\mathrm{pH}$ prevent vascular blockage in stems of cut rose flowers by reducing the number of bacteria. J. Amer. Soc. Hort. Sci. 115:979-981.

van Doorn, W.G. 1997. Water relations of cut flowers. Hort. Rev. 18:1-85. van Doorn, W.G., Y. de Witte, and R.R.J. Perik. 1989. Effect of antimicrobial compounds on the number of bacteria in stems of cut rose flowers. J. Appl. Bacteriol. 68:117-122.

van Doorn, W.G. and M.S. Reid. 1995. Vascular occlusion in stems of cut rose flowers exposed to air: Role of xylem anatomy and rates of transpiration. Physiol. Plant. 93:624-629.
Xue, J., Y. Li, H. Tan, F. Yang, N. Ma, and J. Gao. 2008. Expression of ethylene biosynthetic and receptor genes in rose floral tissues during ethylene-enhanced flower opening. J. Expt. Bot. 59:2161-2169.

Zieslin, N. 1989. Postharvest control of vase life and senescence of rose flowers. Acta Hort. 261:257-264. 